\title{
A pedagógusok szakmai tanulásának támogatása a hazai szabályozást segítő dokumentumokban
}

\author{
Szivák Judit,' Fazekas Ágnes, ${ }^{2}$ Horváth László, ${ }^{3}$ \\ N. Tóth Ágnes, ${ }^{4}$ Salát Magdolna ${ }^{5}$
}

${ }^{1}$ ELTE PPK habilitált egyetemi docense ${ }^{1}$

${ }^{2}$ ELTE PPKtudományos segédmunkatársa

${ }^{3}$ ELTE PPK egyetemi adjunktusa,

${ }^{4}$ ELTE PPK habilitált egyetemi docense

${ }^{5}$ ELTE PPK egyetemi tanársegéde

Vizsgálatunk az Eötvös Loránd Tudományegyetem Pedagógiai és Pszichológiai Kara MoTeL projektjének kutatási eredményeihez kapcsolódik. A tanárok folyamatos szakmai fejlődésére irányuló MoTeL projektet az Országos Tudományos Kutatási Alap (OTKA) támogatja. Tanulmányunk a pedagógusok tanulását meghatározó rendszerkörnyezetet vizsgáló elemzési keretrendszert mutatja be. Kutatásunk célkitüzése ugyanis a pedagógusok szakmai fejlődésével és tanulásával kapcsolatos célok, elvárások, a támogató rendszer és a szakmai fejlődéshez kapcsolódó ellenörző mechanizmusok feltárása. Jelen tanulmányban a képzési és kimeneti követelmények (KKK), az önértékelési kézikönyvek és a karrierfejlesztés útmutatóinak dokumentumelemzését és annak megállapitásait vázoljuk. Elsősorban analitikai keretrendszerünket, munkaorientált kutatási kérdéseinket és a kutatási szempontokat világítjuk meg. Négy kulcsfontosságú elemzési dimenzió - célok, tanulás, támogatás és kontroll-funkciók - mentén vizsgáljuk az egyes központi szabályozó dokumentumoknak a szakmai fejlódésre irányuló befolyását, a szabályozás területeit, eszközeit és mértékét.

Kulcsszavak: pedagógus, pedagógusképzés, folyamatos szakmai fejlódés, dokumentumelemzés, analitikai keretrendszer

DOI: 10.37205/TEL-hun.2019.3-4.02

Az ELTE PPK Neveléstudományi Intézetében zajló, a pedagógusok folyamatos szakmai fejlődését vizsgáló MoTeL projekt keretei között került sor a pedagógusok tanulása szempontjából meghatározó rendszerkörnyezet feltérképezésére. Tanulmányunk a fenti OTKA kutatás eredményeihez kapcsolódik. ${ }^{2}$

\footnotetext{
${ }^{1}$ Levelező szerző: Szivák Judit, ELTE PPK, 1075, Budapest, Kazinczy utca 23-25. E-mail: szivak.judit@ppk.elte.hu

${ }^{2}$ A 128738 számú projekt a Nemzeti Kutatási Fejlesztési és Innovációs Alapból biztosított támogatással, a K_18 pályázati program finanszírozásában valósult meg. A rendszerkörnyezetet vizsgáló kutatócsoport
} 
A kutatás keretében végzett elemzés célja az volt, hogy a vizsgált szabályozást segítő dokumentumokban feltárja a pedagógusok szakmai fejlődésével, tanulásával kapcsolatban milyen célok, elvárások fogalmazódnak meg, milyen támogatóeszközök segítik azok elérését, valamint milyen ellenőrző funkciók működnek ezekhez kapcsolódóan. Jelen tanulmányban a tanári képzési és kimeneti követelmények (továbbiakban KKK), a tanfelügyeleti és önértékelési kézikönyvek, valamint a pedagógus életpálya minősítési útmutatóinak elemzését mutatjuk be.

A tanulmány elsőként az elemzési keretrendszert, a munkát orientáló kutatási kérdéseket és vizsgálati szempontokat ismerteti. Ezt követően a négy kiemelt elemzési szempont - célok, tanulás, támogatás, ellenőrzés-értékelés - mentén vizsgálja, hogy az egyes dokumentumok milyen területeken, eszközökkel és mértékben segítik a pedagógusok folyamatos szakmai fejlődését.

\section{Elemzési keretrendszer bemutatása}

Vizsgálatunk célja a pedagógusok szakmai fejlődését, tanulását meghatározó rendszerkörnyezet elemzése azért, hogy feltárjuk, milyen célokat, elvárásokat fogalmaz meg, miként támogatja azok elérését, valamint milyen ellenőrző funkciókat müködtet e rendszer (1. táblázat).

Az elemzési keretrendszer alapvetően négy blokkban fogalmazta meg a kutatási kérdéseket. A blokkok a rendszerkörnyezetet abból a szempontból kívánják megragadni, hogy azok milyen feltételeket teremtenek a pedagógusok szakmai fejlődése számára. E feltételek tematikus csomópontjai alapján fogalmaztuk meg a kutatási kérdéseket a szakmai fejlődéshez kötődően: milyen célok, tanulási eredmények jelennek meg a dokumentumokban; milyen tanulási folyamat, illetve milyen tanuláskép jellemzi a dokumentumokat; milyen támogatási rendszer definiálódik a célok elérése érdekében; milyen értékelő-ellenőrző rendszer biztosítja a célok eléréséről a visszajelzést és összességében mennyire érvényesül a fentiek tekintetében a jogi szabályozó és a működési folyamatokat orientáló dokumentumok koherenciája és komplexitása. 
Dokumentum Keletkezés Mit szabályoz Kinek szól Funkciója

Képzési- és Kime-

neti Követelmé-

nyek

Önértékelési

kézikönyvek

Minősítési

kézikönyvek

Tanfelügyeleti

kézikönyv
2013

0

0

0

1. táblázat. Az elemzésben felhasznált dokumentumok

Az elemzési keretrendszer a kutatási kérdésekhez (célok, folyamatok, támogatás, ellenőrzés-értékelés) kötődően azonosította a releváns dokumentumokat és elemzési szempontokat, indikátorokat. Az egyes dokumentumokban meghatározásra kerültek a vizsgálati szempontoknak megfelelő szöveggel alátámasztható tények vagy éppen tényszerü hiányok, melyek alapján minden elemzési szempont mentén rögzítettük az adott indikátorhoz tartozó kutatói megállapításokat és reflexiókat.

\section{A tanárok tudásához kötődő elvárások}

A következőkben a hazai szabályozás tanári képesítési követelményeinek és a jogszabályokat segítő, a múködést szabályozó dokumentumainak a megállapításait foglaljuk össze a pedagógusok szakmai fejlődéséhez kötődő célok, támogatási formák és az ellenőrzés-értékelés kapcsán.

\section{A tanárszakok képzési és kimeneti követelményei}

A folyamatos szakmai fejlődés koncepciója ma már elválaszthatatlan a pedagógusok képzésétől és munkájától mind európai (Stéger, 2015), mind hazai dimenzióban (Rapos, 2015). Ennek alapvető elemei a tanárképzésben a reflektív gondolkodás fejlesztése (Szivák, 2014), a szakmai együttműködés (Rapos, 2015), az autonómia (Kennedy, 2005), valamint az aktív tanulás és a saját tanulásról való gondolkodás fejlesztése.

Az elemzés keretéül választott modellek a folyamatos szakmai fejlődés (FSZF) paradigmájában vizsgálják a tanári professziót. A tanárszakok képzési és kimeneti követelményeinek (KKK) vizsgálatában azért relevánsak ezek, mert a KKK-ban a 
tanárok tudásával kapcsolatban megfogalmazott elvárások adják a tanári életpálya és az iskolákban végzett tanári munka kereteit.

Judyth Sachs 2007-es munkájában (Sachs, 2007) a folyamatos szakmai fejlődés (FSZF) modelljeinek leírásában az alábbiak szerint különbözteti meg a jellemző tanárképeket:

- a technicista (technician): számára a tanítás a tanulók tanulásának menedzselését jelenti. A tanítás gyakorlati megközelítése a fontos: a tantermen belül történő releváns és azonnali tevékenységek, válaszok jelentik az elsődleges célt. Itt a tanári fejlődés fókusza új készségek elsajátitása és fejlesztése.

- a mester (craft worker): itt a tanítás előadásként értelmezhető, és a tanár feladata lekötni és szórakoztatni a tanítványait. Ebben a megközelítésben a folyamatos szakmai fejlődés a tanárok tartalmi és pedagógiai tudásának javítását jelenti.

- a reflektív tanuló (reflective learner): az így értelmezett tanár számára a tanítás a gyerekekre való figyelést, az ő szempontjaik mérlegelését és a döntésekbe való bevonásukat jelenti. Ebböl a nézópontból a folyamatos szakmai fejlődés eredménye a tanulókkal kapcsolatos új megközelítések, nézőpontok kialakulása.

- az autonóm szakértő (autonomous professional): munkájában a tanítás az osztálytermi helyzet kutatáson alapuló megoldását jelenti. Ebben a munkában van elég tér és idő a tanárok és diákok számára fontos kérdések megfogalmazására és válaszok megtalálására. „A folyamatos szakmai fejlo"dés során új tudás jön létre”(Sachs, 2007. 18-19.).

Menter és munkatársai (2010) szintén négy paradigmát különböztetnek meg a tanári professzióban:

1. A hatékony pedagógus modellje domináns az elmúlt harminc év kormányzati politikáiban. A modell a tanár munkáját gazdasági szempontból közelíti, kiemelve annak a gazdasági fejlődésben betöltött szerepét. A hangsúly a technikai készségeken és a teljesítmények mérésén van. Ez a modell jól összehangolható egy elóíró tantervvel és egy mérési rendszerrel, ami nem csak a tanárképzésben, de a közoktatásban is tetten érhető.

2. A reflektív pedagógus modellje a tevékenységet egy körkörös folyamatként mutatja be: tervezés - döntés - cselekvés - adatgyüjtés - adatelemzés, értékelés - reflexió - a következő elem tervezése - lépéseket azonosít a 
munkában. Magában hordozza a gyakorlat során végzett reflexió követelményét.

3. A kutató pedagógus munkájának központi eleme a vizsgálódás. Bár a reflektív modell is magában hordozza az adatgyüjtést, de ebben a modellben a pedagógus osztálytermi munkájának rendszeres és rendszerszerủ vizsgálata, gyakorlatának fejlesztése és az eredmények megosztása kerül a középpontba. Az együttműködés köre kitágul: fontossá válik a felsőoktatási intézményekkel való együttműködés.

4. Az átalakitó tanár modelljének újdonsága a társadalom-(át)alakító szerep megfogalmazása. A fenti elméletek elemei mellett itt a társadalmi változáshoz való „aktivista” hozzájárulás jelenik meg. Az átalakító tanár munkájában törekszik tanulóit a társadalomban való aktív részvételre, a társadalmi változásokban betöltött aktív szerepre felkészíteni. A modell szerint fontos a pedagógusok saját értékeinek és nézeteinek is szerepet szánni fejlődési folyamatukban. (Menter és mtsai, 2010. 21-24.)

Ezek alapján látható, hogy a modellek a tanári és tanulói munka fókusza felől fordulnak a tanulás, a kutatás majd a tanári és tanulói aktivitás felé (1. táblázat).

\begin{tabular}{lcc}
\hline \multicolumn{1}{c}{ Sachs, 2007. } & A tanári munka fókusza & Menter és mtsai, 2010. \\
\hline technicista & 0 & 0 \\
mester & 0 & 0 \\
reflektív tanuló & 0 & 0 \\
autonóm & 0 & 0 \\
& 0 & 0
\end{tabular}

1. táblázat: A tanári professzió modelljei és a köztük lévő kapcsolat (Menter és mtsai., 2010; Sachs, 2007)

A követelményeket megfogalmazó KKK a képzés céljaként egy összetett, sok forrásból táplálkozó tanárképet jelenít meg, amely több ponton értelmezhető a fenti modellekkel: a végzett tanárok a NAT és a kerettantervek céljai alapján, saját tudásukat használva végzik a műveltség közvetítését és a kulcskompetenciák fejlesztését. Széleskörủ tudásuk van a tanulókról, a tanításról és a pályaválasztási, gyermek- és ifjúságvédelmi, szociális és nevelési tanácsadási feladatokról. Képesek innovációban, fejlesztésben részt venni. Személyiségük és értékrendjük képes közvetíteni az európai és a nemzeti értékeket. Együttműködésre és önfejlesztésre képesek. Ennek a célnak az elérése érdekében a KKK egy jól kidolgozott és részletes leírását adja a tanári felkészítés követelményeinek. 
A KKK alapvetően a tanári tevékenységekhez kapcsolva jeleníti meg a fejlesztendő kompetenciákat, ezeket a kompetenciákat ismeretek, készségek, képességek és attitűdök összességeként jeleníti meg.

Ebben a megközelítésben a tanár olyan szakember képét mutatja, aki diákjai sajátosságaira építve, az ő tanulási folyamataikat szem előtt tartva végzi munkáját. A személyiségfejlesztést egy diákközösségben végzi, kihasználva annak erőforrásait és sajátosságait. Tervezése és értékelése differenciált, de alapvetően tartalomhoz kapcsolódik. Munkájának fontos eleme az együttműködés, melyben konkrét helyzetek megoldására törekszik, de képes innovációs folyamatokban is részt venni. Munkájában képes reflektíven részt venni, és alakítani a saját környezetét. Ezzel a szakmai fejlődésben elmozdul a funkcionális (technicista) szinttől a mester tanár képe felé (Sachs, 2007). Azzal, hogy a reflexió képessége a tervezéssel, szaktárgyi felkészültséggel és a csoportokról való tudással kapcsolatban is megjelenik, az elvárásokban megjelenik a Menter-modell reflektív pedagógusa (Menter és mtsai, 2010).

Ugyanakkor a képzés szerkezetének bizonyos vonásai a technicista tanár képét rajzolják meg: az erős szakterületi dominancia, az egyes képzési elemek koherenciájának hiánya és a szintetizálás nehézsége hagyományosan, a tudás tartalmaira és annak közvetítésére fókuszáló tanárt mutat. Ebben a képzési szerkezetben nem adottak a szaktárgyi, pedagógiai és gyakorlati tudást integráló, a folyamatos szakmai fejlődés autonómiáját és felelősségét működtetni képes tanári tudás felépülésének körülményei. Ezt a nézőpontot erősíti, hogy a KKK szakterületi leírásai (és a köznevelésben a NAT) erősen tartalomközpontúak és elóíró jellegúek.

Ezekhez a közös követelményekhez kapcsolódnak az egyes szakok sajátos szakmódszertani, tantárgy-pedagógiai elvárásai, melyek a követelményeket a saját szaktárgyra nézve értelmezik, emelik ki annak speciális feladatait, lehetőségeit. Több közülük az általános kompetencia meghatározásoktól eltérő szerkezetű és tartalmú. A szakmódszertani felkészítés tartalmi elemeinek fókuszában nem kompetenciák, hanem döntően a diszciplínákhoz köthető szaktárgyi tartalmak iskolai rendszerezése, felhasználása áll.

A KKK vizsgálatakor fontos szempont lehet, hogy a végzést követő életpálya egyes szakaszainak modelljei milyen módon jelennek meg a jelöltekkel szemben támasztott elvárásokban. Az életpálya első két (kötelezően „elérendő” szakaszában a visszajelzés és minősítés alapját a KKK-ban meghatározott kompetenciaelvárások adják standardizált formában. 
A mesterpedagógus fokozathoz kötődő négydimenziós tevékenységmodell egyes összetevőihez szükséges tudáselemek előremutató módon már szerepelnek a tanári felkészítés és az egyes szaktárgyi modulok elemei között is:

- Pedagógiai munkájában felmerülő problémákhoz képes adekvát szakirodalmat keresni, felhasználni.

- Jól tájékozódik a pedagógiai és szaktárgyi szakirodalomban, képes elemezni, értelmezni e területek kutatási, fejlesztési eredményeit, tisztában van a pedagógiai kutatás, fejlesztés, valamint innováció sajátosságaival.

- Képes egyszerübb kutatási módszerek használatára (KKK 2. sz. melléklet, 1.7.2.), képes megszerzett tudása, gyakorlata alapján, alkotó módon, részt venni oktatásfejlesztési programokban.

- Érett autonóm, kialakult értékrendjükben az általános emberi, az európai és a nemzeti értékeket felvállaló, közvetíteni tudó, együttmúködésre és önfejlesztésre képes, kreatív személyiségek. (KKK 1. sz. melléklet - A tanárképzés általános követelményei).

A fenti, korszerűnek tekinthető elvárások azonban nem jelennek meg a teljes életpálya koherens tanárképzési modelljeként.

A kutatótanár fokozathoz szükséges elvárások közül a pedagógiai vizsgálódás iránti elkötelezettség és a szakirodalmi tudás bővítésének képessége explicit módon is feltünik a KKK elvárásai között, de nyilvánvalóan nem tudja megjeleníteni ez a szabályozás azt a komplex tudásrendszert, melyet a fokozat igényel.

Amennyiben az elemzés fókuszát a szakmai fejlődés irányába fordítjuk, megállapíthatjuk, hogy a szakmai fejlődés egyik alapvető elemeként azonositható reflektivitás fejlesztése célként bukkan fel a KKK szövegében: a saját tudásra, munkára történő folyamatos reflexió megjelenik az egyes kompetenciákhoz kötötten és önállóan is, a tanári felkészítés és az egyes szakok leírásaiban, valamint a portfólió követelményében is (KKK 1. melléklet 4.5.). 
A szakmai együttmüködés a tanulók fejlesztéséhez és az innovációhoz kötötten jelenik meg, azonban a szakmai szervezetben való közös munkavégzés, ami a tanári szakmai fejlődés egyik alapja lehet (Rapos, 2015), nem jelenik meg a KKK tematikájában. A csoportok, közösségek müködése (3. kompetencia) csak a tanulói csoportok nézőpontját hordozza, a 7. kompetenciában megjelenő együttműködéshez köthető tudáselemek pedig nélkülözik a szervezeti kontextust, inkább az intézményrendszerre koncentrálnak. A tanárjelöltek az autonómia és felelősségvállaláshoz kapcsolódó elvárásokat megismerik a KKK-ból, de ezek a követelmények már nem egységesen fordulnak elő az egyes szakok programjaiban.

A jelöltek aktív tanulása és tanulási folyamatukra való reflexió elemei adottak a tanárképzésben: a KKK kidolgozottsága „mintaértékü” (Rapos - Szivák, 2015), azonban a kompetenciák „szintezése” nem történt meg: nem látható, hogy az egyes képzési fázisokhoz milyen tanulási eredmények kapcsolódnak. A kompetenciák fejlődése nem egyenletes a képzésben: az egyes összetevők közül a közös felkészítés inkább az ismeretekre és a nézetekre, a gyakorlat pedig a képességelemekre lesz hatással (Falus, 2006). Mindeközben feltételezhető, hogy az összefüggő egyéni iskolai gyakorlat során megtapasztalt gyakorlati sokk (Szivák, 1999) a hallgatók tudásának önértékelését nem pozitív irányba befolyásolja, ezért fontos lenne a kompetenciák sztenderdjeit a képzés számára is kialakítani, támogatva ezzel a jelöltek tanulását (Rapos és mtsai., 2015).

Összességében elmondható, hogy a megvizsgált jogszabály a tevékenységei mentén írja le a pedagógus képét és az ehhez szükséges tanári tudást. Ezek a tevékenységek alapvetően a gyermekek és csoportok fejlesztési folyamataihoz kötődnek. A jogszabály nem ad egyértelműen leírható képet a tanári professzióról: bizonyos (leginkább tartalmi) elemei a tanuló tanárt, míg szerkezeti és szervezési megoldásai a hatékony tanárt állítják a középpontba. A szakmai fejlódés explicit elvárásként nem jelenik meg, annak csak elemei fedezhetők fel a vizsgált leírásokban.

A KKK a folyamatos szakmai fejlődés alapját, „kulcsát” jelentő reflektivitást kompetenciaként értelmezi, és az egyes szaktárgyi leírásokban is visszatérő elvárásként fogalmazza meg a továbbképzési rendszer és a továbbképzési lehetőségek ismeretét, ám a szakmai fejlődés modelljét nem körvonalazza. Az egyes kompetenciaelemek esetlegesen, egymástól függetlenül vannak jelen a szövegben. A reflektivitás így horizontálisan, minden képzési célként meghatározott kompetenciában felbukkan, de nem szerveződik a szakmai fejlődés modelljévé. 


\section{Célok a pedagógusok szakmai fejlődését, tanulását meghatározó rendszerkörnyezet folyamatszabályozó dokumentumaiban}

A pedagógusok szakmai kompetenciáinak változása, monitorozása és támogatása hangsúlyos része a tanfelügyeleti dokumentumoknak. A rendszer átfogó és deklarált célja az iskolák, illetve a bennük dolgozó pedagógusok szakmai fejlődésének támogatása, ennek megfelelően a tanfelügyeleti rendszer önmagát „fejlesztő értékelés"- ként azonosítja, illetve az értékelési sztenderdek között különböző perspektívákból megközelítve is megjelenik a szakmai fejlődés vizsgálata. Az értékelési rendszer struktúrájában a fejlődés fókuszú perspektíva domináns jelenléte érzékelhető: az ellenőrzési folyamat kimenete egy személyre szóló szakmai fejlesztési terv. A tanfelügyeleti kézikönyvek egésze kifejezetten érzékeny a pedagógusok tanulásának munkahelyi környezetére, illetve figyel a szervezeti működés tanulószervezeti jellegére. A tanfelügyeleti kézikönyvekben megfogalmazott tanárkép olyan pedagógusokban gondolkodik, akik aktív tagjai lehetnek egy tudásintenzív és tanulószervezetként múködő intézményi közösségnek. Ezt mutatja, hogy az egyes pedagógusokkal szemben támasztott elvárásként jelenik meg a szakmai tudás megújítása, a kollégákkal való kooperáció és a tudásmegosztás.

$\mathrm{Az}$ önértékelési dokumentumokban az önértékelési folyamat logikája alapján egy reflektív pedagógussal szemben elvárható követelmény bontakozik ki, hiszen az önértékelés során a pedagógusok reflektív kompetenciáikat kell, hogy alkalmazzák. Az önértékelés szorosan kapcsolódik a tanárképzés képzési és kimeneti követelményeihez, illetve a tanfelügyelet és a pedagógusminősítés szempontrendszeréhez, ezáltal hangsúlyozva a folyamatos szakmai fejlődéshez szükséges egységes kompetencia- és elvárásrendszert, azonban az Önértékelési Kézikönyvben explicit módon nem történik utalás erre a dimenzióra. A szakmai fejlódés gyakorlatilag az önértékelési folyamat fó célja, minden szinten és területen az erősségek és a fejlesztendő területek feltárására és egyéni fejlesztési tervek megfogalmazására épít a dokumentum. A felépitett ciklikus rendszer (korábbi fejlódési terv felülvizsgálata, elórehaladás értékelése) jó lehetőségeket biztosit a folyamatos szakmai fejlódés tudatos épitésére mind egyéni, mind vezetői és szervezeti szinten, de ez a megvalósítás minőségének esetlegességétől függ, így a dokumentum jelenlegi szintjén lehetőség van annak konform, megfelelési kényszerből való intelligens megvalósításra is.

A Minősitési Útmutatókban a vizionált professzióképet az előmeneteli rendszer alsóbb fokozatain (Gyakornok, Pedagógus I. és Pedagógus II.) a nyolc pedagógus kompetenciához rendelt sztenderdek körvonalazzák, a magasabb fokozatokban 
(Mesterpedagógus, Kutatótanár) ezek teljesítettségéből kiindulva, többdimenziós tevékenységmodellekhez tartozó elvárások testesítik meg. A szabályozási környezet a mester és kutató pedagógusok minősítő eljárása kapcsán a korábbi fokozatokhoz képest koncepcionális váltást képvisel. A kompetenciák mesteri szintjén kívül aktív részvételt vár el a szakemberektől a pedagógiai innovációk megvalósítása, a támogató vagy ellenőrző alrendszer működése, illetve a szakmai vezetés tevékenységei terén is (mesterpedagógus profilok). A fokozatba kerülés kritériuma a tevékenységmodell dimenzióihoz rendelt elvárások: a feltáró-kutató tevékenység, az újitó tevékenység, a tudásmegosztó tevékenység és a folyamatos szakmai fejlődés teljesítése. A fokozat hosszútávú megtartása éppen a tudatos szakmai fejlődés révén, annak ötévenkénti megújításával lehetséges, tehát megállapítható, hogy a pedagógusok szakmai fejlődése iránti rendszerszintű célokat az előmeneteli rendszerben való továbbhaladás fejezi ki.

\section{A pedagógusok tanulása a pedagógusok szakmai fejlődését, tanulását meghatározó rendszerkörnyezet folyamatszabályozó dokumentumaiban}

Az osztatlan tanárképzés szabályozása - a pedagógusok szakmai fejlődésére irányuló fejlesztési programokkal összhangban - felismeri az egyéni tanulási utak fontosságát. A KKK-ban meghatározott kompetenciák jól orientálják a képzésben résztvevőket a képzés céljával és eredményeivel kapcsolatban, de az egyéni tanulási folyamathoz kötődő koncepció az alapelvek szintjén sem érvényesül.

A KKK szabályozásában jellemzően formális keretek között, és előre meghatározott utak mentén történik meg a tanulás, ami nem társas tevékenység. A folyamat eredménye autonóm, szakmai munkájáért felelősséget vállalni képes szakember, ám a folyamatban nem azonosítható ennek az autonómiának és kompetenciának a megtapasztalása.

A tanfelügyeleti kézikönyvekben a pedagógusok tanulása igazodik a fejlesztési rendszerkörnyezet kapcsolódó elvárásaihoz: reflektív és szervezeten belüli társas tanulásként értelmezödik. A tanfelügyeleti rendszerben a pedagógusok tanulását önfejlesztési terv, fejlesztési terv és az iránymutatást elötérbe helyezö ellenőrzés-értékelés szabályozza. A tanulási szakaszokat az ellenőrzések alkalmai határolják, amelyekből ötévente legalább egy megvalósul. A tanulási-fejlődési folyamat az ellenőrzés kritériumai szerint meghatározott, a szakértők fontos szerepet kapnak: meghatározó szerepet töltenek be a személyes és intézményi fejlesztési célok 
megvalósulásának megítélésében. Bár a folyamatban lehetővé válik a helyi kontextus figyelembevétele, a tanfelügyeleti kézikönyvek viszonylag kevés támogatást adnak a szakértőknek ahhoz, hogy a gyakorlatban képesek legyenek a helyi feltételekhez igazodni. A megjelenő elvárások listája stabil, nincsenek benne egymást kiváltó elemek, illetve nem tisztázott az önértékelés mögött álló tanulási folyamatok szerepe.

Az önértékelési dokumentumokban megjelenö önértékelési folyamatot értelmezhetjük olyan tanulási folyamatként is, amely szempontokkal és eszközökkel támogatott. A tanulás/fejlődés mint folyamatos felülvizsgálat, önreflexió jelenik meg, amely különböző forrásokból/érintettektől származó visszajelzésekre épül. A folyamatot tanulásként értelmező szemlélet azonban kevésbé érvényesül, a kézikönyvek inkább az önértékelés lebonyolításának technikai sajátosságait írják le, és kevésbé a pedagógusok tanulásának támogatását szolgálják. A tanulás definíciója nem jelenik meg expliciten a dokumentumban, de világosan látható a leírásból, hogy az önértékelések, társértékelések és különböző visszajelzési csatornák működése fontos tanulási folyamat lehet az intézmény és az egyének számára, de ezek hasznosulása, tényleges felhasználása a pedagógusok szakmai fejlődése szempontjából már intézményfüggő.

A minősitési rendszerben a szakmai fejlődést/tanulást, átfogó pedagógus kompetenciák, sztenderdek értelmezik, meglétüket pedig az eljárás során indikátorokkal vizsgálják. A nyolc tanári kompetenciában való fejlődés tanulási célként és eredményként egyaránt értelmezhető, de a tanulási folyamat nézőpontjából nem orientáló. A kívánatos fejlődést a Pedagógus I. fokozatba lépéshez az indikátorlistának való 60 százalékos megfelelés fejezi ki, a Pedagógus II. fokozatba kerüléshez már 75 százalékos teljesítmény szükséges. Kérdés, hogy a százalékokban meghatározott fejlődési elvárás a folyamatos szakmai fejlődéshez kötődő igények és motívumok erősítését miként szolgálja.

A mesterpedagógus és/vagy kutatótanár kategóriákra pályázók tudatos és önirányított tanulási folyamata vezet a fokozat megszerzéséhez, a tanulási folyamatok a mesterprogramok egyéni, autonóm tervezése és megvalósítása által valósulnak meg. 


\section{Támogatás megjelenése a pedagógusok szakmai fejlődését, tanulását meghatározó rendszerkörnyezet folyamatszabályozó dokumentumaiban}

A tanárképzés esetében támogató elemként, résztvevőként azonositható a mentor, vezetőpedagógus és a felsőoktatási tanárképző szakember: ők támogatják a gyakorlati képzés során a jelölt tanulását. E támogató szereplők tudásáról, a támogatás tevékenységeiről a felsőoktatási intézmények helyi szabályozásai rendelkezhetnek. Ezek mellett az egységes értékelési rendszer portfóliója is értelmezhető támogató elemként, bár explicit célja nem ez, hanem a végzős jelölt szummatív értékelése. A szabályozásban keverednek az értékelési (ami az értékelő funkcióra utal) és a fejlődési (ami a támogató funkcióra utal) portfólió elemei.

A tanfelügyeleti rendszerben a pedagógusok szakmai fejlődését az értékelési rendszer egésze: az önértékelési gyakorlatok, az önfejlesztési tervek, a szakértői ellenőrzések és a fejlesztési tervek hivatottak segíteni. A pedagógus által végzett kötelező önértékelő tevékenység elemein túl más támogatási eszköz nincs. A helyi feltételeknek megfelelő tanulási folyamatok támogatásának módszerei helyett az ellenőrzésértékelés tartalmi kritériumai uralják a dokumentumokat, és a rendszer - tartalmilag túlszabályozott és kevéssé rugalmas jellege miatt - szöveghű szakértői alkalmazás mellett csak egy jól meghatározható iskolai kör és azok pedagógusai számára adhat valós támogatást tanulási folyamataikhoz.

Az önértékelési kézikönyv által felvázolt folyamat egy, a pedagógusok folyamatos tanulását támogató környezetként értelmezi a köznevelési intézmények működését azáltal, hogy a működés során és az érintettektől gyűjtött információk és visszajelzések alapján a pedagógusok, a vezetők és az intézmény fejlesztési tervet kell, hogy megfogalmazzanak. Erről a komplex összefüggésrendszerről és a rendszerben fellelhető szinergiákról az önértékelés folyamata nem szól, és bár világos kereteket és folyamatot ad, a tartalom mögötte kevésbé definiált.

Az elömeneteli rendszerben elvárt szakmai fejlődést támogató alrendszerként a mentorálás, szaktanácsadás, a továbbképzések, a szakmai ellenőrzés úgy funkcionálnak, hogy szerepük, jelentőségük, felelősségük a pontos körülhatárolás hiányával küzd. A tanulást támogató környezet elemei kevés kivétellel minden fokozatnál azonosak. Egységesen biztosított például a minősítés jogi feltételrendszere, az elérhető útmutatók, dokumentumminták, a központi informatikai rendszer és a független minősítő bizottságok. Gyakornok esetében ezek a felkészítés/mentorálás le- 
hetőségével egészülnek ki, míg a Pedagógus II. fokozatra pályázók egyéni tanulási utak során készülnek fel a minősítési eljárásra.

A támogató rendszer részletes leírása a Mesterpedagógus fokozatnál történik meg. Ennek értelmében a pályázó pedagógust intézményének szűkebb és tágabb szakmai környezete és a rendszer maga is támogatja. Az előmeneteli rendszer támogató jellege abban nyilvánul meg, hogy lehetőséget teremt egyéni és közösségi mesterprogram benyújtására. Közös mesterprogramban az együtt pályázók a feladattervek végrehajtásában egymás támogatóiként segítik annak megvalósulását. A mesterprogram terveinek elkészitéséhez fontos támogató a külső együttmüködő partner, valamint támogató szerep hárulhat egy konzulensként részt vevő másik mesterpedagógusra is a tervezési és/vagy megvalósítási folyamatban.

\section{Az ellenőrzés-értékelés megjelenése a pedagógusok szakmai fejlődését, tanulását meghatározó rendszerkörnyezet folyamatszabályozó dokumentumaiban}

Az ellenőrző funkció a tanárképzést leíró jogszabályokban explicit módon van jelen. A képzési folyamat végén jelenik meg, célja a pályára bocsáthatóság megállapítása és a szummativ értékelés. A képzést lezáró értékelés eszközei a záróvizsga, a szakdolgozat és a portfolió, az anyanyelvi kritérium-vizsga és a diploma megszerzéséhez szükséges nyelvvizsga követelmények teljesítése. A KKK nem szabályozza a képzési folyamat közben történő értékelések funkcióit és eszközeit, tehát nem tartalmaz formatív értékelési elemet, ezt azonban a képzési programok szintjén megjeleníthetik az egyes képzési helyek. Mivel azonban a kompetenciák szintjének meghatározása csak a képzés végéhez kapcsolódóan történt meg, így nincs jelen a formatív értékelést támogató eszköz a folyamatban, így a rendszer pillanatnyilag nem képes a záró értékelés szempontrendszerének folyamat közbeni alkalmazására.

A tanfelügyeleti rendszer egésze a pedagógusok munkájának és fejlódésének ellenőrzésére épül a nyolc pedagógus kompetencia mentén, mely egyben orientálja és keretet is ad a pedagógusok szakmai fejlődésének. A rendszer követéses, egyszerre ellenőrző és értékelő funkcióval valósul meg, mely az aktuális kompetenciák felmérése mellett a változásra/fejlődésre is összpontosít. A legalább öt évente megvalósuló ellenőrzés több forrásból gyưjt adatokat. Részét képezi az iskolák müködését bemutató dokumentumok vizsgálata, helyi szintű értékelések elemzése, 
megbeszélésekkel kísért óralátogatások végzése és interjúk készítése. Az ellenőrzési rendszer fejlesztési tervvel zárul.

Az önértékelési rendszer ellenőrzési pontjai közül számos elem közvetlenül, míg mások közvetetten kapcsolódnak a pedagógusok tanulásához, és a pedagógusok tanulásának szervezeti dimenziója erősen megjelenik az értékelési standardok között. Mindemellett a legnagyobb kockázati tényezőt a rendszer merev múködése jelenti, hiszen a dokumentumok megfogalmazzák a helyi feltételekhez való igazodás szükségességét, az indikátorlista nem képes biztosítani a személyre/intézményre szabott tanulási folyamatok monitorozását és támogatását, és bár az értékelési rendszer a pedagógusok tanulási folyamatának kereteit hivatott megteremteni, ez egyben fenntartói döntések alapjául is szolgálhat.

A köznevelés-fejlesztési stratégia az „állami visszajelző rendszerek kiépítése” érdekében a „külső szakmai ellenőrzés és értékelés” szisztémájának bevezetését tartja célravezetőnek, ennek érdekében a pedagógus minősitési rendszer céljai a hazai köznevelési rendszer fejlesztésének igényéből kerülnek levezetésre. A kiemelt célok: a köznevelés rendszerének eredményesebbé tétele, a pedagóguskompetenciák értékelésében országosan egységes rendszer kialakitása, a nevelö-oktató munka eredményességének növelése, a minőség elismerése és jutalmazása, a pedagógusok hivatásbeli továbbfejlődésének ösztönzése, valamint a pedagógusok motiválása saját teljesítményük javítására.

A kompetenciákhoz rendelt sztenderdeknek Pedagógus I. fokozatba kerüléshez 60 százalékával, Pedagógus II. fokozatba kerüléshez 75 százalékával kell rendelkezni, sikertelen vizsga vagy eljárás után mindkettő ismételhető. Az ismételt vizsga sikertelensége a munkaviszony megszűnését vonja maga után.

Az ellenőrzés szereplói a vizsgán és az eljárásban is a bizottság elnöke, a pályázó pedagógus minősítésre kerülő szakjával azonos szakos szakértő, a pályázó intézményének delegált résztvevője, a pályázó szakmai közössége, az Oktatási Hivatal által kijelölt szakértő, esetleg fenntartói delegált és/vagy auditor, gyakornok esetében a mentor.

A struktúrában felfelé haladva a minősítés tartalmában a Pedagógus II. és Mesterpedagógus fokozatok között lényeges eltérések tapasztalhatók. Míg a minősítő rendszer alsóbb fokozatainál a külső, szakértői ellenőrző funkció határozottabb, addig a magasabb kategóriák pályázóinak ellenőrzésébe a szűkebb-tágabb szakmai közösség is bekapcsolódik. Az eljárásban minőségi különbséget jelent az eljárás összetettsége, az ellenőrzési-értékelési folyamat értelmezését segítő tevékeny- 
ségmodellek, a folyamatba bevont/bevonható szereplők affiliációja is, de még az eljárás folyamatát leíró útmutatók kidolgozottsága is.

A minősitó eljárás a fokozatszerzés időszakában megitélt fejlettség keresztmetszetrōl képes visszajelezni, a szakmai fejlődés folyamatosságáról, közbülső állomásairól azonban nem. Az ellenőrzés mechanizmusainak müködése a fokozatszerzés időszakában a pályázat benyújtásától a minősítés megszerzéséig erőteljes, a várakozás időszakában a minősítéstől a következő minősítő eljárás kezdetéig, főleg az alacsonyabb kategóriáknál (Pedagógus I. és II.) szórványos.

\section{A szabályozó dokumentumok közötti koherencia}

A jogi szabályozást segítő dokumentumok elemzésének meghatározó kérdése, hogy mennyiben alkotnak koherens rendszert a jogi szabályozó dokumentumokkal.

A pedagógusok folyamatos szakmai fejlődése tekintetében a köznevelési stratégia pontos diagnózist nyújt a hiányosságok, fejlesztendő területek tekintetében (például az alapképzésbe nagy átfutással épülnek be az eredmények, az alap- és továbbképzés nem alkot egységes rendszert, a köznevelés új kihívásaira nem, vagy késéssel reagál a rendszer, a pedagógusok módszertani kultúrájában lévő hiányosságok stb.), és a dokumentum utal a támogató rendszer hiányára is, de a stratégia általában nem kínál megoldási javaslatokat. Megjelenik ugyan az egyénre szabott, gyakorlatorientált szaktanácsadói rendszer elképzelése néhány konkrét eszközzel (például szaktanácsadói kompetenciák kialakítása, szaktanácsadók szerepe a szakmai fejlődési folyamat elősegítésében), de a hangsúlyos elem az ellenőrzésen van.

Összességében a pedagógus professziókép és folyamatos szakmai fejlődés tekintetében a jogszabályi környezet rendkívül tagolt, polarizált. Noha maga a köznevelési stratégia sem ad megfeleló kiindulási alapot, de még ha viszonyitási pontként el is fogadjuk, a jogszabályi környezet arra vagy nem reflektál, vagy válaszai nem érdemiek. A Nemzeti köznevelési törvény, annak végrehajtási rendelete és a Műkr. ${ }^{3}$ alapján kirajzolódó pedagóguskép szerint a tanár nem autonóm szereplő, akinek tevékenysége, ideértve szakmai fejlődését saját igényességéből és a szakmai közösség elvárásaiból fakadva, a közösség által támogatottan és a közös fejlödéshez hozzájárulva szolgálja a közjót, s amelyhez a köznevelési rendszer minden

${ }^{3}$ 20/2012. (VIII. 31.) EMMI rendelet a nevelési-oktatási intézmények működéséről és a köznevelési intézmények névhasználatáról. 
támogatást megad. Sokkal inkább alkalmazott, a köznevelési rendszer egy eleme, akinek működése szigorú rendben ellenőrizendő, és elégtelenség esetén hasonló eréllyel szankcionálandó.

Míg a pedagóguskép és a vele szembeni elvárások tekintetében kirajzolódik egy mégoly vitatható, de egyértelmú kép, a tanulási folyamat, s különösen annak támogatása lényegében átfogó szabályozás nélkül marad. A részleges szabályozottság, illetve a szabályozott területek esetében a belső ellentmondások, illetve lefedetlen területek eredményeképpen azzal szembesülhetünk, hogy a jogszabályi háttér nem komplex, nem koherens és nem is konzekvens. Ez a kép magyarázza, hogy nem fogalmazható meg olyan egységes állitás, miszerint a hazai jogszabályi környezet a pedagógusok folyamatos szakmai fejlődését összességében támogatná vagy gátolná. A hazai jogszabályi környezetben összességében a támogatás önálló szabályozást nem nyer, az egyes jogszabályokban a támogatás mint megvalósítandó feladat, illetve annak felkínált eszközrendszere nem jelenik meg.

\section{A hazai szabályozás törekvései a professziómodellek tükrében}

A dokumentumok rendszerszintű elemzése lehetőséget ad arra is, hogy a kutatásunk során feltárt fejlődés- és professziómodellek mentén jellemezzük a hazai szabályozás törekvéseit.

A nemzetközi térben elfogadott professziómodellek lehetőséget adnak az egyes nemzeti szakpolitikák elemzésére, különös tekintettel arra, hogy a rendszerek szabályozásában mely funkciók dominálnak.

Napjaink egyik meghatározó szakmai tematikája a pedagógus professzió jellemzése kapcsán a szakmai és szervezeti professzió fogalmai. A szakmai professzió modellje (Hargreaves - Goodson, 1996; Evetts, 2011) a pedagógusok fejlődésének meghatározó forrásaként az autonómiát említi. A modell szerint a pedagógus autonóm döntése alapján jelöli ki a fejlődés céljait, tevékenységeit, a középpontban tehát az egyén tudása és általa meghatározott fejlődése áll, beleértve az egyén szakmai környezetének tudására gyakorolt hatását és e hatás kölcsönösségét (Evetts, 2011).

A szakmai professzió mellett egyre jelentősebb szerepet kap a rendszer által meghatározott szervezeti professzió (Gorman - Sandefour, 2011; Sachs, 2016; Torres - Weiner, 2018). A szervezeti professzió elméletében a fejlődés céljának, tartalmának meghatározása elsősorban a rendszer elvárásai felől érkezik, a középpontban a pedagógus elszámoltathatósága, munkájának standardok segítségével törté- 
nő ellenőrzése áll (Evans, 2008; Sachs, 2016). A fejlődés forrása tehát az irányító rendszer külső elvárásai, amelyek mentén nyomon követhetővé, elszámoltathatóvá válik a pedagógus tevékenységének eredményessége, annak érdekében, hogy a rendszert irányítók céljainak képviselete minél hatékonyabban érvényesülhessen.

A fenti elméleti modellek mentén jellemezhetővé válik egy szabályozási rendszer közelsége - távolsága az autonómiára, illetve az elvárásokra/elszámoltathatóságra épülő professzió felfogásokhoz képest.

Egy másik megközelítésben, Lester (2014) szerint a szakma-kompetenciák kialakításában alapvetően két eltérő modell van jelen. A két modellt: foglalkozás(occupational) és professzió- (professional) modellnek nevezi.

A foglalkozás-modellre alapvetően a funkcionalista megközelítés jellemző, vagyis lényegében az adott szakma tevékenységeinek leírása. A szakma eredményessége érdekében munkavégzési szakaszokat azonosít és ír le, s azokhoz standardokat rendel. Többen rámutattak arra, hogy mivel részletes leírásokat tartalmaz, ezért képtelen a változást értelmezni, holott az, hogy egy szakmában kit tekintünk „kompetensnek” változhat, de még akár az eltérő kontextus is más-más tevékenységeket követelhet meg. Erénye a modellnek ugyanakkor, hogy rámutat: a kompetencia „belso” felépítése (ismeret, készség, attitűd) elégtelen elmélet, sokkal inkább szükséges egy „külső”, holisztikusabb nézőpont. Hangsúlyozza, hogy „kompetenssé” nem a kompetencia tesz önmagában, hanem az, hogy képes-e a személy azt a környezetnek megfelelően alkalmazni. A kritikák nem jelentik azt, hogy a hivatás-modell mára irrelevánssá vált volna, ugyanis támogathatja a fejlôdést, a képzési kimeneti követelmények kialakítását és a minőségbiztosítási értékeléseket is. 
A professzió-modell esetében is hangsúlyozni kell, hogy a fókuszban itt nem a professzió mint társadalmi konstrukció, hanem a professzionális munkavégző mint a professzió ágense áll. A foglalkozás-modellel ellentétben ez a megközelítés nem tevékenységekre, hanem képességekre, alkalmasságra koncentrál. Fókuszukban az alapkompetenciák állnak, s sokkal inkább a fejlődésre, mint az értékelésre koncentrálnak. Hátrányuk, hogy minőségbiztosítási célokra csak korlátozottan alkalmazhatóak, ugyanis ezek az értékelések elsősorban a tevékenységekre koncentrálnak. Újabban a modell egyre inkább a „capabilities” fogalomra épül, mert a „competent” szakember képes számos helyzetben professzionálisan dolgozni, viszont a „capable” szakember új ismereteket is el tud sajátítani, vagy éppen létrehozni. A professzió-modellre továbbá jellemző az is, hogy a kompetenciát nem egy fix pontban, hanem sokkal inkább egy skálán képzeli el.

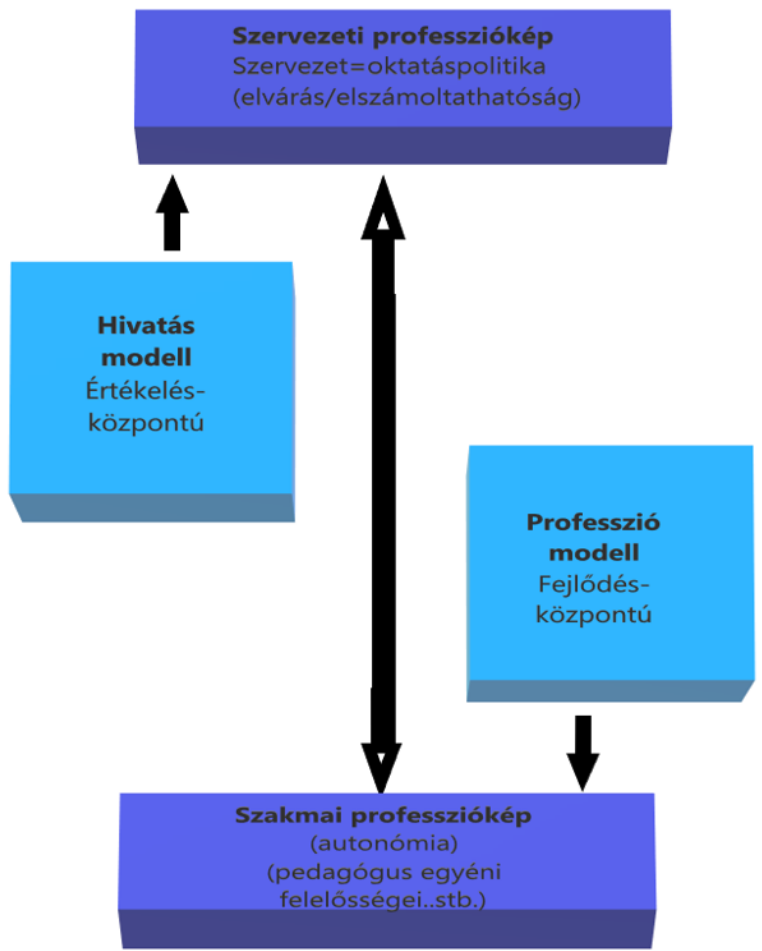

1. ábra: Professziómodellek

A fenti két elméleti modell egyesítésével (lásd 1. ábra), kirajzolódik a dokumentumok elemzésének legfontosabb megállapítása, miszerint a hazai jogi szabályozórendszer alapvetően az elszámoltathatóságot helyezi a középpontba, a pro- 
fesszió fejlődéséhez kötődően az ellenőrzés eszközrendszerét preferálja, a jogi szabályozást és a működési folyamatokat segítő dokumentumok tartalma inkább fejlődés orientált, de funkciójukat tekintve egyértelműen az ellenőrzéshez-értékeléshez kötődnek.

\section{Az elemzett dokumentumok}

8/2013. (I. 30.) EMMI rendelet a tanári felkészítés közös követelményeiről és az egyes tanárszakok képzési és kimeneti követelményeiről. URL.: https://net.jogtar.hu/jogszabaly?docid=A1 300 008.EMM\&celpara $=\&$ dbnum $=1$

Útmutató a pedagógusok minősitési rendszerében a pedagógus I. és pedagógus II. fokozatokba lépéshez. Ötödik, javított változat. Az emberi erőforrások minisztere által 2013. november 19-én elfogadott általános tájékoztató anyag ötödik, javított változata.

Útmutató a mesterpedagógus fokozatot megcélzó minősitési eljáráshoz. Harmadik, javított változat.

Útmutató a kutatótanár fokozatot megcélzó minősitési eljáráshoz. Harmadik, javított változat.

Köznevelés-fejlesztési stratégia, Budapest, 2014.

Magyar Köztársaság (2005): A Magyar Köztársaság Kormányának Stratégiája Az Egész Életen Át Tartó Tanulásról. Budapest.

Okos köznevelés (NOIR+) dokumentum. A dokumentum 'A pedagógusminősítési rendszer kiegészítése, kipróbálása és korrigálása a TÁMOP-3.1.5/12-2012-0001 azonosító számú projekt' keretében készült.

Önértékelési kézikönyv gimnáziumok számára. Negyedik, javított kiadás. Oktatási Hivatal, Budapest, 2019.

\section{Irodalom}

Earl, L. - Watson, N. - Levin, B. - Leithwood, K. - Fullan, M. - Torrance, N. (2003): Watching \& Learning 3, Final Report of the External Evaluation of England's National Literacy and Numeracy Strategies. Ontario Institute for Studies in Education, Toronto.

Evans, L. (2008): Professionalism, professionality and the development of education professionals. British fournal of Educational Studies, 56 évf., 1. sz. 20-38.

Evetts, J. (2011): A New Professionalism? Challenges and Opportunities. Current Sociology 59. évf., 4. sz. 406-422. 
Pedagógusképzés • 18(46), 2019/3-4.

Európai Bizottság (2014): Monitoring and evaluation of European Cohesion Policy. Online: https://ec.europa.eu/regional_policy/sources/wikiguidance/ gn0160_esf_monitoring_and_evaluation.pdf

Falus Iván (2006): A tanári tevékenység és a pedagógusképzés új útjai. Gondolat Kiadó, Budapest.

Gorman, E. - Sandefour, L. (2011): “Golden Age," Quiescence, and Revival. Work and Occupations, 38. évf., 3. sz. 275-302.

Hargreaves, A. - Goodson, I. F. (1996): Teachers' professional lives: Aspirations and actualities. In I. F. Goodson, - A. Hargreaves (szerk.), Teachers professional lives. Farmer Press, London. 1-27.

Kennedy, A. (2005): Models of continuing professional development: a framework for analysis. Fournal of In-service Education, 31. évf., 2. sz. 235-250. URL: https://www.tandfonline.com/doi/pdf/10.1080/1367 4580500200277 Utolsó letöltés: 2019. október 16.

Lester, S. (2014): "Professional standards, competence and capability", Higher Education, Skills and Work-Based Learning, 4. évf., 1. sz. 31-43.

Menter, I. - Hulme, M. - Elliot, D. - Lewin, J. (2010): Literature Review on Teacher Education in the 21st Century. Scottish Government Social Research.

OECD (2004): Innovation in the Knowledge Economy. Implications for Education and Learning. Paris.

OECD (2013): Innovative Learning Environments, Educational Research and Innovation. OECD Publishing.

OECD (2014): Measuring Innovation in Education: A New Perspective, Educational Research and Innovation. OECD Publishing.

Rapos Nóra (2015): A támogatás értelmezései a személyes szakmai életúton. In: Vámos Ágnes (szerk.): Tanuló pedagógusok és az iskola szakmai tókéje. ELTE Eötvös Kiadó, Budapest. 79-102.

Rapos Nóra - Kopp Erika - Czető Krisztina - Kálmán Orsolya - Mészáros György - Tókos Katalin - Seresné Busi Etelka (2015): Javaslat az osztatlan tanárképzés gyakorlati rendszerének átgondolására és a jelenlegi gyakorlatok alapelveinek és funkcióinak meghatározására. In: Rapos Nóra és Kopp Erika (szerk.): $A T a-$ nárképzés Megújítása - 2015. ELTE Eötvös Kiadó, Budapest. 215-282.

Rapos Nóra - Szivák Judit (2015): Az osztatlan tanárképzés KKK-elemzésére épülő alapelveinek, képzési struktúrájának és tartalmának meghatározása. In: Rapos Nóra és Kopp Erika (szerk.): A Tanárképzés Megújítása - 2015. ELTE Eötvös Kiadó, Budapest. 11-32. 
Sachs, J. (2007): Learning to improve or improving learning: the dilemma of teacher continuing professional development. In: Proceedings of the 20st Annual World ICSEI Congress. 3-6.

Stéger Csilla (2012): Tanárképzési helyzetkép a bolognai reformok után. Doktori disszertáció. ELTE Neveléstudományi Doktori Iskola. URL:

https://doktori.hu/index.php?menuid=193\&lang=HU\&vid=9459 Utolsó letöltés: 2019. október 16.

Szivák Judit (2014): Reflektív elméletek, reflektív gyakorlatok. ELTE Eötvös Kiadó, Budapest.

Torres, A. C. - Weiner, J. (2018): The New Professionalism? Charter Teachers' Experiences and Qualities of the Teaching Profession. URL:

https://epaa.asu.edu/ojs/article/view/3049

\section{The support of teachers' professional learning as reflected in regulatory documents}

Our study relates to the results of MoTeL project of the Faculty of Education and Psychology, Institute of Education at Eötvös Loránd University. MoTeL project is supported by the Hungarian Scientific Research Fund (OTKA) and focuses on teachers' continuous professional development (CPD).

This study explored the system-environment as an analytical framework determining teachers' learning. The aim of our analysis was to reveal the goals and expectations related to teachers' CPD and learning; supporting tools that help them to achieve their learning goals; and the control functions related to their CPD.

In this study, we present an analysis of teacher training content and outcome requirements (KKK); instructional and self-assessment manuals; and guidance for teacher career development. (Instructions for teachers involved in the 2016 certification process). This study primarily presents the analytical framework, workoriented research questions, and research aspects. Our analysis examines the areas, tools, and extent to which each document contributes to the CPD of teachers, along the four key analytical dimensions - goals, learning, support and control evaluation.

Keywords: teacher, teacher training, professional development, document analysis, analytical framework 